\title{
The relationship between different approaches to multifunctionality of agriculture and choice of methods: A critical review
}

\author{
Monika Korzun $^{\text {a }}$ \\ University of Guelph
}

Submitted November 19, 2013 / Revised February 1, April 30, July 5, and November 29,

2014, and January 5, 2015 / Accepted January 5, 2015 / Published online March 8, 2015

Citation: Korzun, M. (2015). The relationship between different approaches to multifunctionality of agriculture and choice of methods: A critical review. Journal of Agriculture, Food Systems, and Community Development, 5(2), 109-128. http://dx.doi.org/10.5304/jafscd.2015.052.009

Copyright (C) 2015 by New Leaf Associates, Inc.

\begin{abstract}
The concept of multifunctionality in agriculture is significant to both academia and policy development. Agriculture can serve multiple purposes in addition to the production of food and fiber. It can aid in addressing environmental, economic, and social issues faced by rural communities. The purpose of this study is to explore and describe the relationship between how scholars make use of multifunctionality and what methods they apply to the study of this concept. The article first identifies five types of approaches to multifunctionality: a market and economically focused approach, a rural land-use approach, an ecological approach, a public regulation and policy approach, and an actororiented approach. Secondly, applying the method
\end{abstract}

\footnotetext{
a Monika Korzun, PhD student, Rural Studies; School of Environmental Design and Rural Development; University of Guelph; Guelph, Ontario N1G 2W1 Canada; +1-289997-7753; mkorzun@uoguelph.ca
}

of content analysis, the article examines 50 primary research studies on multifunctionality in the context of agriculture. The hypothesis of this article is that each identified concept of multifunctionality will coincide with a type of method. The article concludes that certain approaches correspond to certain research methods, which can limit the development of multifunctionality as a concept and practice.

\section{Keywords}

multifunctionality, political decision-making, research methods, theoretical inquiry, content analysis, policy, agroecology

\section{Introduction}

The notion of multifunctionality of agriculture first emerged in the Agenda 21 documents of the Rio Earth Summit in 1992 in the context of sustainable development and food security (Caron et al., 2008; Wilson, 2008). After the 1992 summit, the 
Organization for Economic Co-operation and Development (OECD) further expanded the concept. Scholars and various organizations like the OECD use the term multifunctionality to illustrate that agriculture has one or more functions in addition to its primary role of producing food and fiber (OECD, 2001). This article will illustrate that the term arose from a variety of disciplines and can be used in numerous ways and for various purposes, depending on the geographical scope and political framework.

Multifunctionality was first recognized as an economic activity to help keep producers afloat by providing additional employment as well as alternative and profitable markets (Renting et al., 2008). As such, multifunctionality at this time was being discussed as a positive rather than a normative concept (Caron et al., 2008). The positive approach defines multifunctionality as the jointness of outputs. Jointness examines the relationship between commodities or private goods and noncommodity outputs or public goods. Here, commodity and noncommodity outputs are interdependent throughout the production process. The role of policy development is to interfere when there is a lack of markets for noncommodity outputs (OECD, 2001). The concept of multifunctionality has also evolved as a normative concept with a value in itself, recognizing and encouraging the wide array of services that rural communities and agriculture can provide. This latter approach has been accepted by the European Union (EU) and utilized in its agricultural reforms (Wilson, 2008). In addition to the OECD, the concept of multifunctionality has also been discussed in various political arenas such as the World Trade Organization (WTO), Food and Agriculture Organization (FAO) of the United Nations and the Common Agricultural Policy (CAP) in the EU.

Although the concept of multifunctionality continues to be applied in a variety of ways, scholars and organizations generally use the term to illustrate that rural communities and agriculture serve a wide variety of social, economic, and environmental functions beyond producing food and fiber. Haugan, Nyland, Fjeldavli, Meistad and Braastad (2006) use multifunctionality to examine the ways in which Norwegian agriculture and rurality are suited to providing physical and mental health services, also known as "green care." From an environment perspective, Jordan and Warner (2010) examine the ways in which growing perennials and continuous living cover crops in the upper Midwest region in the United States can regenerate soil health and increase biodiversity that has been negatively affected by corn and soybean farming.

As the concept of multifunctionality is utilized in a wide variety of ways, it is important to explore how scholars define, investigate, and apply the concept. The purpose of this study is twofold: to categorize the ways in which multifunctionality is examined and to describe the relationship between how scholars utilize the concept of multifunctionality and the methods they apply to the study of this concept. The study is an exploratory and qualitative study to introduce the topic and encourage researchers and policy-makers to broaden their approach to studying multifunctionality. The correspondence between concepts and type of method will be examined and tested here using the concept of multifunctionality. Based on the examination of various academic journals and discussion papers, five types of approaches to multifunctionality will be identified: a market and economically focused approach, a rural land-use approach, an ecological approach, a public regulation and policy approach, and an actor-oriented approach. The hypothesis of this article is that each identified concept of multifunctionality coincides with a type of method.

\section{The Various Approaches to Multifunctionality}

Although the term multifunctionality generally refers to the notion that rural communities and agriculture can serve functions beyond the production of food and fiber, this concept has been applied by researchers and policy-makers in a variety of ways. Many authors link the wide variety of approaches to specific scientific backgrounds and epistemologies (Caron et al., 2008; Renting et al., 2008; 2009).

Although classifications of concepts can take different forms, be categorized using different criteria, and vary on the level of detail, the work by Renting et al. (2008; 2009) and Caron et al. (2008) 
is a good starting point. Renting et al. (2008; 2009) discuss various applications of multifunctionality and propose an integrated model that can be applied to the study of multifunctionality. Caron et al. (2008) develop clusters of the concept and provide a unique outlook by examining the scientific and political motivations that have altered the meaning of the word. Renting et al. (2009) touch on the types of disciplines that are most likely to utilize a specific approach to multifunctionality. However, no scholars to date have examined the types of methods that correspond to the types of approaches. After an extensive review of literature, the author has identified five approaches to utilizing the concept of multifunctionality. The next five subsections describe the approaches to multifunctionality and serve as a guideline to understanding the various studies and literature on this topic. Although these approaches are described separately, this does not suggest that there is no overlap between these concepts, nor that researchers do not combine more than one approach simultaneously.

\section{Market and Economically Focused Approach}

Many authors have used multifunctionality focusing solely on the economic aspects of the concept. Multifunctionality here is defined as an economic activity that has multiple outputs, including commodity outputs and noncommodity outputs. Multifunctionality is based on the aspect of jointness between these outputs. Both types of outputs are seen as having a market value, despite the notion that noncommodity values often do not have an established market and have to find other means of evaluation and compensation (Van Huylenbroeck \& Durand, 2003). An example of jointness is a farmer who raises cows on a pasture. Here, one economic activity (raising cows) can satisfy society by proving food (meat) and land management of grazing systems and grasslands. These outputs are seen as economic activities of a production process (Abler, 2004; Adamowicz, 2003). Caron et al. (2008) claim this is the most neoliberal approach and represents the positive version of multifunctionality that was presented in the early writings of the OECD. It is important to note that this mostly positive approach does not altogether exclude normative functions of multifunctionality.

Researchers utilizing this approach often ask the question of how to develop markets for noncommodity outputs. Renting et al. (2009) claim that many authors focus on examining how separate markets for noncommodity outputs can be created in a way that do not disturb markets for commodity outputs. Many studies, as illustrated by the sample below, attempt to determine whether, and if so how, farmers should be compensated for their noncommodity outputs, such as landscape management or environmental protection. This approach does not challenge market mechanisms, established agricultural institutions and belief systems, or international trade negotiations. Under this approach, public intervention is only necessary when policy formations are required to develop markets for noncommodity outputs.

\section{Rural Land-use Approach}

Whereas the above approach focuses on the economic aspects of multifunctionality, the rural landuse approach directs attention to the territorial aspects of multifunctionality. The concern is with how land is managed and what changes will or will not take place to the physical structure of the land. Often, farmers and farms as a unit are not taken into consideration in this approach. The social processes at the farm and decision-making about managing the land are also not taken into consideration. Decisions about the land are made at an aggregate level. This approach is very normative; the aim is to provide evidence for objectives such as redirecting funds, reinforcing a diverse economy, and promoting alternative functions of agriculture such as landscape management.

Disciplines such as rural planning, landscape architecture, geography, landscape and conservation ecology, and regional economics often utilize this approach by focusing on the location where the land use change will take place. Social aspects, such as regional employment and strength of social networks, or the functions and the activities taking place at this location, are often secondary or neglected altogether (Rossing, Zander, Josien, Groot, Meyer, \& Knierim, 2007). Researchers employing this method are concerned with ques- 
tions around managing the physical landscape while factoring in the aesthetic and ecological impacts of agriculture (Renting et al., 2009). Where other approaches ignore this, the land-use approach often takes into consideration resilience of crops and ecosystems and the impacts of climate change on the region in question (Atwell, Schulte, \& Westphal, 2010; Jordan \& Warner, 2010). Biodiversity conservation, watershed management, and forestry and wildlife management are some of the topics covered under this approach. This research contributes to the discussion of sustainable development since rural land use can have immense effects on landscape and the environment.

\section{Ecological Approach}

Although the rural land-use approach takes into consideration the ecological aspects of multifunctionality, it is secondary to the concern of land management and physical changes to the land. The main concern of the ecological approach to multifunctionality is the impact of agriculture on the environment; it proposes solutions that challenge the industrial agricultural system. This approach recognizes the contribution of intensive farming to air and water pollution, loss of biodiversity and wildlife habitat, and soil erosion and degradation. It recognizes that the agricultural sector contributes to the catastrophic events of climate change. Fields of environmental studies and geography often use this approach when describing multifunctionality. Specifically, agroecology and landscape ecology promote the principles of this approach. Agroecology utilizes ecological principles to manage ecosystems found on farm land. It was developed, Lovell et al. (2010) claim, to counter industrial agriculture.

Jordan and Warner (2010) propose multifunctionality as a strategy that can meet current human needs while sustaining ecosystems and protecting them for the use of future generations. McGranahan (2014) claims that multifunctionality can help marry the usually competing processes of agricultural production and conservation of biology. He points to the notion that an ecological approach to agriculture does not result in the rejection of industrial agriculture, but can help create a more sustainable system with less use of fossil fuels and greater conservation and protection of ecological systems, while maintaining productivity and profitability.

Recognizing the contribution of the agricultural sector to the degradation of the environment, the ecological approach also views the agricultural sector and farming practices as contributors to the solutions. Under this approach farmers are seen not only as food producers but also as environmental stewards and active participants in formulating and undertaking solutions to bettering the ecological landscape. Several studies in the United States examine how multifunctionality can help restore some of the environmental damage caused by the predominance of industrial agriculture. For example, using participatory methods and interviews, Atwell, Schulte and Westphal (2010) conducted a participatory workshop with agricultural, environmental, and policy leaders in the Corn Belt in Iowa to better understand diminished conservation land and develop practices as a way to achieve ecological as well as economic and social outcomes in the midst of the increasing markets for cornbased ethanol. The participatory workshop not only helped stakeholders recognize the complexity of the Corn Belt, it helped facilitate the formation of partnerships and perennial conservation initiatives that will help increase agricultural production while serving the ecosystem. These studies encourage U.S. farm policy that not only works within the framework of industrial agriculture and increasing yield and profits, but also takes into consideration the environmental benefits agriculture and farmers can produce.

\section{Public Regulation and Policy Approach}

This approach focuses on the institutional and policy aspects of multifunctionality. Although this approach is policy-driven, it has the capacity to challenge conventional policy and program management and thus also to challenge conventional approaches to agriculture and rural development. This approach can be classified as normative in the sense that it recognizes the role of political and social institutions in structuring and regulating goods, rather than relying solely on free-market mechanisms. Research under this approach focuses not only on policy formation but also on how these 
policies and programs are being implemented and practiced on the ground. As such, impact assessment falls under this approach. Questions of policy formation and operationalizing public institutions in implementing, facilitating, and monitoring multifunctionality are often the focus for researchers employing this approach. Caron et al. (2008) also found that many authors examine the role of policy formation in managing and controlling conflicts between the commodity and noncommodity markets. Disciplines such as political science, policy evaluation studies, sociology, and economics often utilize this approach.

Within this framework, weak and strong multifunctionality is distinguished and placed on a spectrum. Weak multifunctionality is characterized by the lack of challenge and critique for high-intensity production, environmental degradation, and the power structures that influence mainstream agriculture. Conversely, strong multifunctionality pays close attention to the environment and sustainability. Policies developed under the notion of strong multifunctionality attempt to challenge mainstream agriculture and encourage the development of more inclusive, participatory, environmentally friendly, and territory-oriented programs and farming enterprises (Daniel \& Perraud, 2009; Renting et al., 2009; Wilson, 2008). Strong multifunctionality is more inclusive, represents nonproductivism, and includes part-time, hobby, and selfsustainable farms as having valid roles in rural and agricultural communities.

\section{Actor-Oriented Approach}

The final identified approach is the actor-oriented paradigm. This approach has a wider center of attention and focuses on public goods, such as landscape preservation and biodiversity; goods and services produced for nonfarm markets, including agritourism and energy conservation; and functions of agriculture such as food quality, animal welfare, and quality of life. Like the public regulation and policy approach, this approach has the ability to challenge conventional systems of production and rural policy-making. In addition, this approach has the ability to analyze the food supply chain and the role of multifunctionality in less favored areas, as well as to access various functions within the sus- tainable development framework. Daniel and Perraud (2009) consider this to be the strongest of the multifunctionality approaches as a result of its greater emphasis on increasing the decision-making power of local communities and allowing the communities' unique development needs and agendas to prevail.

Researchers ask questions about the impact of a function on employment, income, social interactions, and migration patterns; how to promote the various functions in a specific region or community; and why farmers or rural communities choose to partake in various functions of multifunctionality (Caron et al., 2008). This approach attempts to illustrate how these various functions can contribute to the local community, region, and society at large, taking into consideration farmers, the farm, and other local stakeholders as the units of analysis. The social interactions between these units of analysis and various functions of multifunctionality are often examined. In addition, there is a greater focus on sense of place as embodying not just the physical landscape that is the basis of the rural land-use approach, but also the social, environmental, political, and economic aspects. Researchers utilizing this approach assume that territorial-based knowledge can formulate policies and programs that take into consideration the possibilities, knowledge, and capacities of specific regions.

\section{Methods}

Content analysis was used to examine and synthesize the sample. Content analysis is a tool to examine human communication, including text, images, and symbolic matter. Researchers applying content analysis place the sample into predefined categories determined by the study's hypothesis (Hale 1995; Lindkvist, 1981). Content analysis operates on the assumption that cultural beliefs systems, viewpoints, and patterns of behavior can be expressed in texts, images, and symbolic matter (Bos \& Tarnai, 1999). Content analysis uses several processes to infer social reality. This study utilizes the frequency technique also known as the classification technique. The frequency technique counts the number of occurrences of a certain word, item, or theme. In this case, the peer-reviewed journal articles, discussions, conference papers, and book 
chapters that used primary data to examine the concept of multifunctionality were coded. The author used the frequency technique to examine the type of primary research method used in the studies on multifunctionality and the type of multifunctionality discussed.

Three main steps were taken to select the articles for this study. First, we chose articles for the study that examined the concept of multifunctionality. We then determined the type of multifunctionality being discussed. The aforementioned descriptions of multifunctionality were used as predetermined codes for the various ways in which researchers discussed multifunctionality. It is important to mention that not all articles used the term "multifunctionality" to describe the topic of examinations. It was, however, evident by the topic under study that the focal topic can be classified as such. For example, farms dedicated to providing health and social services, referred to as "green care," are widely accepted in literature as part of multifunctional agriculture. Haugan et al. (2006) examine green care in Norway and refer to multifunctionality only once in the concluding remarks. The final main criteria for selecting articles was that the study utilized primary data to examine multifunctionality. The type of multifunctionality was then compared to the type of method used. This would aim to answer the hypothesis of this study, whether identified concepts of multifunctionality coincide with a particular type of method.

We gathered the sample using nonrandom purposive sampling, which involves selecting for the sample whatever the researcher judges to have the characteristics necessary for the study. The intent of this sampling is not to generalize from a large sample but to focus on specific characteristics of interest that will best answer the research question. In this case, the methods used in studies focused on multifunctionality are of interest to the researcher. This sampling technique is suitable for studies such as this one, which seeks to explore whether a phenomenon even exists or whether it is worth investigating further.

In total, there are 50 studies in the sample, with 10 studies per category. This was a conscious and deliberate choice, and believed to be sufficient for the purpose of this study. There are other empirical studies on multifunctionality that could be included in an expanded version of this paper. The years of publication for the sample range from 2003 to 2014. The sample covered articles from 24 journals, two books, and eight conferences or seminars. Qualitative and quantitative methods were used, including case studies, interviews, surveys, contingent valuation method, parametric models and scenario development programs. Appendix A summarizes the sample. Appendix B provides complete bibliographic information for all the samples. The studies from the sample were characterized and classified into the appropriate multifunctionality category. The descriptions of the five multifunctionality approaches above were used to classify the units of analysis. The purpose, unit of analysis, and content of each study determined the approach in which the study was placed. After classifying the studies into the appropriate multifunctionality approach, the methods used in the study were examined.

\section{Results}

The results indicate a correlation between the approach to multifunctionality and the choice of research methods used. About half the studies (48\%) used qualitative methods; $42 \%$ t used quantitative methods; and 10\% utilized mixed methods. It is important to mention that some qualitative studies quantified some aspects of their study and used quantitative measures, and vice versa. For example, Haugan et al.'s (2006) study on green care in Norway used a variety of statistical information as a means to describe agriculture in Norway and the green care farmer. In this case, the study was classified as qualitative, as statistical information was used to support the case study. For the purposes of this study, quantifying a qualitative study did not place that research study in the category of "combination of both." To be classified as partaking in both qualitative and quantitative methods, the study had to undertake and follow through with at least one qualitative method and at least one quantitative method and each of these methods had to be taken into consideration in the analysis. A study in the sample on integrated and nonintegrated farming systems in Thailand by Tipraqsa, Craswell, Noble, and Schmidt-Vogt 
Table 1. Type of Method Used by Approach to Multifunctionality

\begin{tabular}{|c|c|c|c|c|c|c|}
\hline \multirow[b]{2}{*}{ Type of Method } & \multicolumn{6}{|c|}{ Approach to Multifunctionality } \\
\hline & $\begin{array}{c}\text { Market and } \\
\text { Economically } \\
\text { Focused Approach }\end{array}$ & $\begin{array}{c}\text { Rural Land-Use } \\
\text { Approach }\end{array}$ & $\begin{array}{l}\text { Ecological } \\
\text { Approach }\end{array}$ & $\begin{array}{c}\text { Public Regulation } \\
\text { and Policy } \\
\text { Approach }\end{array}$ & $\begin{array}{l}\text { Actor-Oriented } \\
\text { Approach }\end{array}$ & Total \\
\hline Qualitative & 0 & 7 & 4 & 5 & 8 & 24 \\
\hline Quantitative & 9 & 2 & 4 & 5 & 1 & 21 \\
\hline Combination of both & 1 & 1 & 2 & 0 & 1 & 5 \\
\hline Total & 10 & 10 & 10 & 10 & 10 & 50 \\
\hline
\end{tabular}

(2007) is a good example of utilizing both qualitative and quantitative methods. In this study, the authors partook in extensive interviews and observations of the farms (qualitative); the second part of the research involved taking soil samples to obtain information such as stem density and organic matter (quantitative). All the information was integrated to form a comparative study of integrated and non-integrated farms in Thailand.

Table 1 illustrates the type of method (qualitative, quantitative, or both) by the approach to multifunctionality. The market and economically focused approach studies used mostly quantitative methods, with $90 \%$ of the methods used in the sample being quantitative. Studies of the rural landuse approach used mostly qualitative methods, with $70 \%$ of methods classified as qualitative, $20 \%$ as quantitative, and $10 \%$ as a combination of both. Forty percent of the studies in the ecological approach used qualitative methods, $40 \%$ were classified as quantitative, and $20 \%$ used a combination of both. The public regulation and policy approach was an even split between qualitative and quantitative. The actor-oriented approach used qualitative methods in $80 \%$ of the sample. Only $10 \%$ of the studies used quantitative methods and $10 \%$ utilized a combination of both techniques.

Table 1 demonstrates that the market and economically focused approach favors quantitative methods, and the actor-oriented approach favors qualitative methods. The remaining three methods are somewhere in between, with the rural land-use approach slightly more in favor of the qualitative side than the ecological and public regulations and policy approaches, which are more evenly spread across the type of method. Using the data above, we can place the approaches to multifunctionality on a continuum of qualitative methods on one end and quantitative on the other (Figure 1). The continuum does not suggest that the types of methods cannot be used together or that they are mutually exclusive. This review of content analysis illustrates that both types of method embody characteristics of one another and that studies often benefit from using both approaches. The continuum is used as a way of simplifying and

\section{Figure 1. Placement of Approaches to Multifunctionality on the Qualitative-Quantitative Continuum}

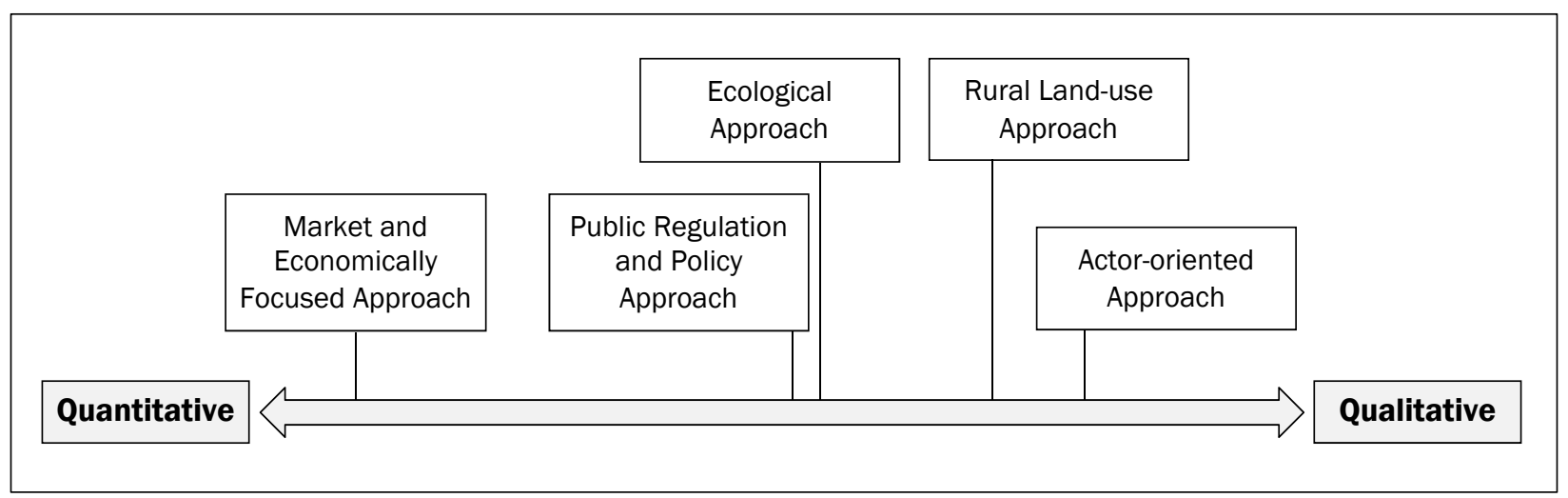


illustrating the table above.

Table 2 illustrates the mode of the methods used in each approach to multifunctionality. The mode refers to the most frequent value in a distribution. Modes are appropriate measures of central tendency for nominal variables. Nominal measurement organizes that data into categories that are mutually exclusive. In this study, the multifunctionality approaches are designed to be a nominal level of measurement. The mode for market and economically focused approach is the method of contingent valuation model (CVM). The most frequent value for the rural land-use approach is the case study, while the interview was most common for the ecological approach. Under the public regulation and policy approach, the most frequently used method was the comparative case study. Finally, the comparative case study and the case study were used in the same frequency under the actor-oriented approach.

\section{Discussion}

One of the trends found in this study is the low number of studies combining qualitative and quantitative methods. Most studies utilized one or the other. There have been numerous debates about the significance and applicability of qualitative and quantitative methods. Many authors point out that researchers are not limited to one method because both can be utilized in one study without sacrificing the validity or reliability of the other. During data gathering and analysis, the researcher can create a dialogue between both methods to gain a better understanding of concepts and of how to represent them. Babbie and Banaquisto (2002) believe that a complete understanding of a concept requires the application of both techniques.

Although there is no absolute relationship between certain types of questions and explanations and methods and techniques, the results of this study suggest that certain approaches do align with qualitative or quantitative methods. The sample of market and economically oriented studies mostly used quantitative methods. Studies under the market and economically focused approach focus on finding a suitable price for noncommodity outputs. Examples include the amount of compensation farmers should receive for environmentally friendly farming practices and how much the public is willing to pay for a particular noncommodity output, such as wilderness protection. Although these might be very suitable techniques for these questions, it would be worth examining the willingness to pay for services from a qualitative perspective. No study in this sample has addressed this issue on a deeper level with the perspectives of local actors taken into account. The issue of willingness to pay for a service is possible to examine by using in-depth interviews or development of scenarios. This would allow a researcher to examine why the public is willing to pay a particular price for that service. Similarly, the actororiented approach focused on qualitative techniques. Although some statistical and numerical data was available in the studies, only one study involved conducting a survey. The study on the role of migrant workers in multifunctional agriculture in Greece by Kasimis, Papadopoulos and Pappas (2010) provided a very detailed and clear picture of the trends and roles of migrants in three agricultural regions in Greece. By using a different technique than is commonly applied to the topic, Kasimis et al. (2010) were able to provide an excellent introduction to an issue that has yet to be examined in depth.

Closer examination of the approaches and methods used suggests that certain approaches do correspond to certain methods. The most common method used in the market and economically focused approach is the contingent valuation model (CVM), which is used to estimate a value for environmental issues. This method was not used 
under any other approach. In their analysis on the various approaches to multifunctionality, Renting et al. (2008) claim that the market and economically oriented approach focuses too much on public goods and externalities. This limits the ability to understand the wide range of functions agriculture can provide. The notion that CVM was the most frequently used method supports this statement. Attempting to quantify noncommercial goods may be questioned by some scholars and practitioners. There are some functions that are classified as multifunctional that may not be marketable, such as food security and social cohesion.

Although the mode of the remaining approaches was the case study or comparative case study, there is a difference in the techniques they used. For example, the most common technique under the rural land-use approach is the technique of scenario development, where a number of options are posed and one selection is chosen as the one to be implemented. These studies focus on where rural land changes will take place but provide very little information on how large the impacted area will be and the consequences of implementing those changes to that area. This information is relevant for sustainable development; depending on the type and amount of inputs and outputs, changes in land use might have devastating consequences for the environment, limiting the application of this approach to questions of multifunctionality. Also, scenario development often ignores social and ecological aspects of the landscape. Renting et al. (2009) also point out that in studies using scenario models, agriculture is often viewed as one of the land uses and functions, rather than an integrated model of functions at the level of agricultural activity.

The ecological approach was quite evenly split between the use of qualitative and quantitative methods; $20 \%$ of the studies utilized both. Although this approach utilized the combination of qualitative and quantitative methods most frequently of all approaches, it does not represent a holistic combination of methods. Similar results can be found in Knickel, Kröger, Bruckmeier, and Engwall's (2009) report on examining evaluation methods of multifunctionality in the EU. Knickel et al. (2009) reported that although a mixture of qualitative and quantitative methods are used, there is very little effort made to integrate the two. Even when both qualitative and quantitative methods are used, they are not used to achieve true triangulation, where a variety of methods and approaches are combined, but are used in separate parts of the research to illustrate separate points. This lack of triangulation can put into question the rigor of the methods and results of the studies in question.

It was within this approach that the only participatory approach was used as a primary research gathering method. To address the environmental challenges associated with the Corn Belt in the U.S., Atwell et al. (2010) invited a variety of agricultural, environmental, and policy leaders to a participatory workshop. The objective of the workshop was to better understand the socio-ecological capacity, resilience, and innovation in the Corn Belt as well as to identify the key obstacles to and opportunities for improving the ecosystem in that region. Participatory research has potential for providing unique perspectives and affecting policy and decision-making. There are also many secondary benefits to participatory research, such as networking and sharing of resources that can help stakeholders.

The public regulation and policy approach used the method of comparative case studies by performing an in-depth examination of various documents. The units of analysis in this approach are mostly complex concepts like multifunctionality, policies, services, and rights. There is an obvious lack of attention given to the local actors and decision-makers. The various policies are examined at an aggregate level. Of all the approaches, the public regulation and policy approach examined the most countries in their comparative studies, comparing on average four countries in a study. When comparative studies were utilized under other approaches, they usually compared two countries, with the exception of Zander et al. (2008), where four countries were compared, classified under the market and economically focused approach. Although these types of studies have contributed greatly to illustrating how different countries use, monitor, and assess the concept of multifunctionality and how multifunctionality fits with wider policy goals of sustain- 
ability and rural development, Renting et al. (2009) believe that the organization, implementation, and evaluation of multifunctional policies is still poorly developed.

The actor-oriented approach used both case studies and comparative case studies. Studies under this approach displayed strength in describing and analyzing multifunctional farming systems, including their personal motivations and challenges and their role in a larger framework of sustainability and rural development. They were also successful in illustrating the synergies between various functions (Renting et al., 2008). What appeared to be lacking was the ability to illustrate how multifunctional activities and decision-making at the local level can contribute to the aggregate level of decision-making. Within this framework, interviews with local actors were very common.

\section{Conclusion}

The discussion above illustrates that the use of only one type of method poses a variety of limitations. These limitations challenge the development of multifunctionality as a concept and practice. Limiting one's examination of a concept, such as multifunctionality, to the use of one method may also expose the study to a critique of lack of triangulation. As illustrated by Table 2 , the most common methods for the entire sample were case studies and comparative case studies. The sample did not include research methods such as process tracing, social mechanisms, and fuzzy set theory. There were only three cases of historical analysis. Only one study utilized participatory methods. The limited use of participatory methods is also represented in Knickel et al.'s (2009) study on evaluation of multifunctional policies and programs. They claim that evaluation of multifunctional policies is directed by experts, while other stakeholders are seen solely as recipients of information. This, Knickel et al. (2009) claim, limits colearning opportunities. The use of diverse methods can provide great value and aid in the development and strengthening of multifunctionality as a concept and a body of research.

This study is meant as an introduction to a topic that has received very little attention. The purpose of this study was to first illustrate the various ways in which multifunctionality is studied. This was done by presenting the five different approaches to multifunctionality. Multifunctionality is present in various disciplines, including social and natural sciences. The multiple uses of multifunctionality have greatly contributed to our understanding of how agriculture can serve several functions in addition to providing food and fiber. By identifying five approaches to multifunctionality, this study supports authors like Knickel et al. (2009), who suggest that we should accept the open and various definitions of multifunctionality. There are numerous social, economical, and ecological benefits. Second, the purpose of this study was to explore and describe the relationship between approaches to multifunctionality and the methods used. The results demonstrate that certain approaches to multifunctionality correspond to certain methods. This may constrain our understanding, as well as constraining the potential of each approach and of multifunctionality as a general concept. Applying different and novel methods and challenging the methods normally used in various disciplines can add to problematizing the concept of multifunctionality.

While recognizing that the size of the sample does not allow for generalization, there is potential to expand this study to make the results statistically significant and to examine other aspects of the relationship between the categories of multifunctionality and the methods used. Further research can also concentrate on comparing the results from the methods used to demonstrate how different methods contribute to the development of a concept and the significance of selecting appropriate methods for specific outcomes. This has helped us better understand the strengths and limitations of multifunctionality as well as the relationship between theory or concept and the method used. The intention here is not to endorse one definition of multifunctionality, but to better understand that multifunctionality can be used in a variety of ways and how those different ways are being studied. The five approaches to multifunctionality allow researchers and decision-makers to better understand how multifunctionality is utilized in various studies. Since multifunctionality of agriculture is not a uniform concept and is examined differently 
by various researchers and policy-makers, distinguishing between the five approaches can help identify opportunities and limitations of various studies. This study suggests that further research would benefit from utilizing a combination of new or underused qualitative and quantitative research methods, including participatory methods, to shed a different light on the concept.

\section{Acknowledgements}

Thank you to Prof. John F. Devlin for his feedback and guidance that contributed to the preparation of this manuscript.

\section{References}

Abler, D. G. (2004). Multifunctionality, agricultural policy, and environmental policy. Agricultural and Resource Economics Review, 33(1), 8-17. http://purl.umn.edu/31376

Adamowicz, M. (2003). Adoption of rural households in Poland to the needs of multifunctional development of rural areas in the regions of former state farm domination. Electronic Journal of Polish Agricultural Universities, 6(2), \#01. Retrieved from http://www.ejpau.media.pl/volume6/issue2/ economics/art-01.html

Atwell, R. C., Schulte, L. A., \& Westphal, L. M. (2010). How to build multifunctional agricultural landscapes in the U.S. Corn Belt: Add perennials and partnerships. Land Use Policy, 27(4), 1082-1090. http://dx.doi.org/10.1016/j.landusepol.2010.02. $\underline{004}$

Babbie, E., \& Benaquisto, L. (2002). Fundamentals of social research. Scarborough, Ontario: Nelson.

Bos, W. \& Tarnai, C. (1999). Content analysis in empirical social research. International Journal of Educational Research, 31(8), 659-671. http://dx.doi.org/10.1016/S0883-0355(99)00032-4

Caron, P., Reig, E., Roep, D., Hediger, W., Le Cotty, T., Barthelemy, D., Hadynska, A., Hadynski, J., Oostindie, H. A., \& Sabourin, E. (2008). Multifunctionality: Refocusing a spreading, loose and fashionable concept for looking at sustainability? International Journal of Agricultural Resources, Governance and Ecology, 7(4/5), 301-318. http://dx.doi.org/10.1504/IJARGE.2008.020078

Daniel, F.-J., \& Perraud, D. (2009). The multifunctionality of agriculture and contractual policies: A comparative analysis of France and the Netherlands. Journal of Environmental Management, 90(Supp. 2), S132-S138. http://dx.doi.org/10.1016/ j.jenvman.2008.11.015

Hale, S. M. (1995). Controversies in Sociology: A Canadian Introduction (2nd Ed.). Toronto: Copp Clark.

Haugan, L., Nyland, R., Fjeldavli, E., Meistad, T., \& Braastad, B. O. (2006). Green care in Norway: Farms as a resource for the educational, health and social sector. In J. Hassink \& M. Van Dijk (Eds.), Farming for health: Green-care farming across Europe and the United States of America (pp. 109-126). Dordrecht, the Netherlands: Springer.

Jordan, N., \& Warner, K. D. (2010). Enhancing the multifunctionality of US agriculture. BioScience, 60(1), 60-66. http://dx.doi.org/10.1525/bio.2010.60.1.10

Kasimis, C., Papadopoulos, A. G., \& Pappas, C. (2010). Gaining from rural migrants: Migrant employment strategies and socioeconomic implications for rural labour markets. Sociologia Ruralis, 50(3), 258-276. http://dx.doi.org/10.1111/j.1467-9523.2010. 00515.x

Knickel, K., Kröger, M., Bruckmeier, K., \& Engwall, Y. (2009). The challenge of evaluating policies for promoting the multifunctionality of agriculture: When 'good' questions cannot be addressed quantitatively and 'quantitative answers are not that good.' Journal of Environmental Policy and Planning, 11(4), 347-367. http://dx.doi.org/10.1080/15239080903033945

Lindkvist, K. (1981). Approaches to textual analysis. In K. E. Rosengren (Ed.), Advances in content analysis (pp. 23-41). London: SAGE.

Lovell, S. T., DeSantis, S., Nathan, C. A., Olson, M. B., Méndez, V. E., Kominami, H. C., Erickson, D. L., Morris, K. S., \& Morris, W. B. (2010). Integrating agroecology and landscape multifunctionality in Vermont: An evolving framework to evaluate the design of agroecosystems. Agricultural Systems, 103(5), 327-341. http://dx.doi.org/10.1016/j.agsy.2010.03.003

McGranahan, D. A. (2014). Ecologies of scale: Multifunctionality connects conservation and agriculture across fields, farms, and landscapes. Land, 3(3), 739-769. http://dx.doi.org/10.3390/land3030739 
Organisation for Economic Co-Operation and Development (OECD). (2001). Multifunctionality:

Towards an analytical framework. Paris: OECD

Publications Service. Retrieved from http://www.oecd.org/tad/agriculturalpolicies/40782727.pdf

Renting, H., Oostindie, H., Laurent, C., Brunori, G., Barjolle, D., Jervell, A. M., Granberg, L., \& Heinonen, M. (2008). Multifunctionality of agricultural activities, changing rural identities and new institutional arrangements. International Journal of Agricultural Resources, Governance and Ecology, 7(4/5), 361-385. http://dx.doi.org/10.1504/IJARGE.2008.020083

Renting, H., Rossing, W. A. H., Groot, J. C. J., Van der Ploeg, J. D., Laurent, C., Perraud, D., Stobbelaar, D. J., \& Van Ittersum, M. K. (2009). Exploring multifunctional agriculture: A review of conceptual approaches and prospects for an integrative transitional framework. Journal of Environmental Management, 90(Supp. 2), S112-S123. http://dx.doi.org/10.1016/j.jenvman.2008.11.014

Rossing, W. A. H., Zander, P., Josien, E., Groot, J. C .J., Meyer, B. C., \& Knierim, A. (2007). Integrative modelling approaches for analysis of impact of multifunctional agriculture: A review for France, Germany and the Netherlands. Agriculture,
Ecosystems and Environment, 120(1), 41-57. http://dx.doi.org/10.1016/j.agee.2006.05.031 Tipraqsa, P., Craswell, E. T., Noble, A. D., \& SchmidtVogt, D. (2007). Resource integration for multiple benefits: Multifunctionality of integrated farming systems in northeast Thailand. Agricultural Systems, 94(3), 694-703. http://dx.doi.org/10.1016/j.agsy.2007.02.009

Van Huylenbroeck, G. V., \& Durand, G. (2003). Multifunctional agriculture: A new paradigm for European agriculture and rural development. Hampshire, UK: Ashgate Publishing Limited.

Wilson, G. A. (2008). From "weak" to "strong" multifunctionality: Conceptualising farm-level multifunctional transitional pathways. Journal of Rural Studies, 24(3), 367-383. http://dx.doi.org/10.1016/j.jrurstud.2007.12.010

Zander, P., Groot, J. C. J., Josien, E., Karpinski, I., Knierim, A., Meyer, B. C., Madureira, L., Rambonilaza, M., \& Rossing, W. A. H. (2008). Farm models and economic valuation in the context of multifunctionality: A review of approaches from France, Germany, The Netherlands and Portugal. International Journal of Agricultural Resources, Governance and Ecology, 7(4/5), 339-360. http://dx.doi.org/10.1504/IJARGE.2008.020084 


\section{Appendix A. Summary of Sample by the Approaches to Multifunctionality}

\begin{tabular}{|c|c|c|c|c|c|c|}
\hline \# & Author(s) & Origin of Article & Year & Method & $\begin{array}{l}\text { Qualitative vs. } \\
\text { Quantitative }\end{array}$ & $\begin{array}{l}\text { Region } \\
\text { Researched }\end{array}$ \\
\hline \multicolumn{7}{|c|}{ Market and Economically Focused Approach } \\
\hline 1 & Zander et al. & $\begin{array}{l}\text { International Journal of } \\
\text { Agricultural Resources, } \\
\text { Governance and Ecology }\end{array}$ & 2008 & $\begin{array}{l}\text { Comparative archival } \\
\text { research }\end{array}$ & Quantitative & $\begin{array}{l}\text { France, Germany, } \\
\text { the Netherlands, } \\
\text { Portugal }\end{array}$ \\
\hline 2 & Aizaki et al. & $\begin{array}{l}\text { Paddy and Water } \\
\text { Environment }\end{array}$ & 2006 & $\begin{array}{l}\text { Contingent valuation } \\
\text { method (CVM) }\end{array}$ & Quantitative & Japan \\
\hline 3 & $\begin{array}{l}\text { Boisvert \& } \\
\text { Blandford }\end{array}$ & $\begin{array}{l}\text { Paddy and Water } \\
\text { Environment }\end{array}$ & 2006 & Partial equilibrium model & Quantitative & Taiwan \\
\hline 4 & Grega & $\begin{array}{l}\text { An Enterprise Odyssey: } \\
\text { International Conference } \\
\text { Proceedings }\end{array}$ & 2004 & Case study & $\begin{array}{l}\text { Quantitative } \\
\text { and } \\
\text { quantitative }\end{array}$ & $\begin{array}{l}\text { South and West } \\
\text { Moravia }\end{array}$ \\
\hline 5 & Hartell & $\begin{array}{l}\text { Journal of Agricultural and } \\
\text { Applied Economics }\end{array}$ & 2004 & $\begin{array}{l}\text { Benefit externality } \\
\text { valuation /E-V quadratic } \\
\text { programming model }\end{array}$ & Quantitative & NA \\
\hline 6 & $\begin{array}{l}\text { Lienhoop \& } \\
\text { MacMillan }\end{array}$ & Land Use Policy & 2007 & $\begin{array}{l}\text { Market Stall approach to } \\
\text { contingent valuation } \\
\text { method (CVM) }\end{array}$ & Quantitative & Iceland \\
\hline 7 & Ohe & $\begin{array}{l}\text { Journal of Environmental } \\
\text { Management }\end{array}$ & 2011 & Fee-determining model & Quantitative & Japan \\
\hline 8 & $\begin{array}{l}\text { Ollikainen \& } \\
\text { Lankoski }\end{array}$ & MTT Discussion Papers 1 & 2005 & Parametric model & Quantitative & Finland \\
\hline 9 & $\begin{array}{l}\text { Hadiger \& } \\
\text { Lehmann }\end{array}$ & $\begin{array}{l}\text { Proceedings of the 35th } \\
\text { International Conference of } \\
\text { Agricultural Economics } \\
\text { (IAAE) }\end{array}$ & 2003 & $\begin{array}{l}\text { Economic static allocation } \\
\text { model }\end{array}$ & Quantitative & NA \\
\hline 10 & Hyytia \& Kola & $\begin{array}{l}\text { 99th seminar of the } \\
\text { European Association of } \\
\text { Agricultural Economics } \\
\text { (EAAE) }\end{array}$ & 2005 & Survey/ Factor analysis & Quantitative & Finland \\
\hline \multicolumn{7}{|c|}{ Rural Land-use Approach } \\
\hline 11 & Turpin et al. & Land Use Policy & 2009 & $\begin{array}{l}\text { Scenarios development } \\
\text { based on a two scale } \\
\text { modelling framework }\end{array}$ & Qualitative & Eure-et-Loir, France \\
\hline 12 & $\begin{array}{l}\text { Sutherland at } \\
\text { al. }\end{array}$ & $\begin{array}{l}\text { Landscape and Urban } \\
\text { Planning }\end{array}$ & 2011 & Survey and interviews & $\begin{array}{l}\text { Qualitative and } \\
\text { quantitative }\end{array}$ & $\begin{array}{l}\text { Four geographic } \\
\text { regions in Scotland }\end{array}$ \\
\hline 13 & $\begin{array}{l}\text { Parra-Lopez et } \\
\text { al. }\end{array}$ & Land Use Policy & 2009 & Case study & Quantitative & The Netherlands \\
\hline 14 & $\begin{array}{l}\text { Haaland, Fry \& } \\
\text { Peterson }\end{array}$ & Landscape Research & 2011 & Case study & Qualitative & Scania, Sweden \\
\hline 15 & Holmes & Geographical Research & 2010 & Historical analysis & Qualitative & Tropical savannah \\
\hline
\end{tabular}




\begin{tabular}{|c|c|c|c|c|c|c|}
\hline & & & & & & $\begin{array}{l}\text { zone of Northern } \\
\text { Australia }\end{array}$ \\
\hline 16 & Aznar et al. & $\begin{array}{l}\text { Multifunctional Land Use } \\
\text { (book) }\end{array}$ & 2007 & Case study & Qualitative & France \\
\hline 17 & $\begin{array}{l}\text { Barbieri \& } \\
\text { Valdivia }\end{array}$ & Journal of Rural Studies & 2010 & Multiple linear regressions & Quantitative & $\begin{array}{l}\text { Four counties in } \\
\text { Missouri, USA }\end{array}$ \\
\hline 18 & $\begin{array}{l}\text { Carvalho- } \\
\text { Ribeiro, Lovett } \\
\& \text { O'Riordan }\end{array}$ & Land Use Policy & 2010 & Case study & Qualitative & $\begin{array}{l}\text { Two parishes in } \\
\text { northern Portugal }\end{array}$ \\
\hline 19 & Saltzman et al. & Journal of Rural Studies & 2011 & Comparative case study & Qualitative & $\begin{array}{l}\text { Sweden and } \\
\text { Australia }\end{array}$ \\
\hline 20 & Soliva et al. & Journal of Rural Studies & 2008 & $\begin{array}{l}\text { Scenario development and } \\
\text { focus groups }\end{array}$ & Qualitative & $\begin{array}{l}\text { Six mountain areas } \\
\text { in Europe }\end{array}$ \\
\hline \multicolumn{7}{|c|}{ Ecological Approach } \\
\hline 21 & Atwell et al. & Land Use Policy & 2010 & $\begin{array}{l}\text { Participatory workshop } \\
\text { and interviews }\end{array}$ & Qualitative & Iowa, USA \\
\hline 22 & Boody et al. & BioScience & 2005 & Scenario development & Qualitative & $\begin{array}{l}\text { Two watersheds in } \\
\text { Minnesota, USA }\end{array}$ \\
\hline 23 & $\begin{array}{l}\text { Hector \& } \\
\text { Bagchi }\end{array}$ & Nature & 2007 & $\begin{array}{l}\text { Statistical analysis - } \\
\text { backward- elimination } \\
\text { multiple regression } \\
\text { analysis }\end{array}$ & Quantitative & $\begin{array}{l}\text { Eight grassland } \\
\text { sites from year } 3 \text { of } \\
\text { the BIODEPTH } \\
\text { project }\end{array}$ \\
\hline 24 & Lovell et al. & Agricultural Systems & 2010 & $\begin{array}{l}\text { Case studies including } \\
\text { interviews and } \\
\text { agroecosystem design } \\
\text { assessment tool }\end{array}$ & Qualitative & $\begin{array}{l}\text { Intervale Center } \\
\text { and Butterworks } \\
\text { Farm in northern } \\
\text { Vermont }\end{array}$ \\
\hline 25 & Schindler et al. & Landscape Ecology & 2014 & Interviews & $\begin{array}{l}\text { Qualitative and } \\
\text { Quantitative }\end{array}$ & $\begin{array}{l}21 \text { experts from } 6 \\
\text { European } \\
\text { countries. } \\
\text { Classification of } 38 \\
\text { floodplains. }\end{array}$ \\
\hline 26 & $\begin{array}{l}\text { Waldhardt et } \\
\text { al. }\end{array}$ & Ecology and Society & 2010 & $\begin{array}{l}\text { Normative multifunctional } \\
\text { landscape scenario }\end{array}$ & Quantitative & $\begin{array}{l}\text { Lower Wetter- } \\
\text { catchment in } \\
\text { Hesse, Germany }\end{array}$ \\
\hline 27 & $\begin{array}{l}\text { Crossman \& } \\
\text { Bryan }\end{array}$ & Ecological Economics & 2009 & $\begin{array}{l}\text { Landscape-scale } \\
\text { biophysical and economic } \\
\text { data and models. }\end{array}$ & Quantitative & $\begin{array}{l}\text { Lower Murray- } \\
\text { Darling Basin in } \\
\text { Australia }\end{array}$ \\
\hline 28 & Milne et al. & The Forestry Chronicle & 2006 & Comparative case studies & Qualitative & $\begin{array}{l}\text { Three regions in } \\
\text { southern Ontario }\end{array}$ \\
\hline 29 & Andersen et al. & Ecological Indicators & 2013 & $\begin{array}{l}\text { Surveys and structured } \\
\text { interviews }\end{array}$ & Quantitative & $\begin{array}{l}\text { Favrskov and } \\
\text { Viborg munici- } \\
\text { palities in } \\
\text { Denmark }\end{array}$ \\
\hline 30 & Lovell et al. & Agroforestry Systems & 2010 & $\begin{array}{l}\text { Spatial landscape analysis, } \\
\text { interviews and statistical } \\
\text { analysis }\end{array}$ & $\begin{array}{l}\text { Qualitative and } \\
\text { quantitative }\end{array}$ & $\begin{array}{l}16 \text { farms in } \\
\text { Lamoille } \\
\text { watershed, }\end{array}$ \\
\hline
\end{tabular}




\section{Public Regulation and Policy Approach}

\begin{tabular}{|c|c|c|c|c|c|c|}
\hline 31 & $\begin{array}{l}\text { Bjorkhaug \& } \\
\text { Richards }\end{array}$ & Journal of Rural Studies & 2008 & Comparative case study & Qualitative & $\begin{array}{l}\text { Norway and } \\
\text { Australia }\end{array}$ \\
\hline 32 & Caron et al. & $\begin{array}{l}\text { International Journal of } \\
\text { Agricultural Resources, } \\
\text { Governance and Ecology }\end{array}$ & 2008 & Comparative case study. & Qualitative & $\begin{array}{l}\text { France, the } \\
\text { Netherlands, } \\
\text { Poland, Spain, } \\
\text { Switzerland }\end{array}$ \\
\hline 33 & Dibden at al. & Journal of Rural Studies & 2009 & Comparative case study & Qualitative & Australia and EU \\
\hline 34 & $\begin{array}{l}\text { Râmniceanu \& } \\
\text { Ackrill }\end{array}$ & Journal of Rural studies & 2007 & Statistical analysis & Quantitative & $\begin{array}{l}\text { Eight EU new } \\
\text { member states }\end{array}$ \\
\hline 35 & Rossing et al. & $\begin{array}{l}\text { Agriculture, Ecosystems } \\
\text { and Environment }\end{array}$ & 2007 & $\begin{array}{l}\text { Quantitative system } \\
\text { modeling/integrative } \\
\text { modelling approaches. }\end{array}$ & Quantitative & $\begin{array}{l}\text { France, Germany, } \\
\text { and the } \\
\text { Netherlands }\end{array}$ \\
\hline 36 & $\begin{array}{l}\text { Sumelius \& } \\
\text { Bäckman }\end{array}$ & $\begin{array}{l}\text { International Journal of } \\
\text { Agricultural Resources, } \\
\text { Governance and Ecology }\end{array}$ & 2008 & Comparative case study & Qualitative & $\begin{array}{l}\text { Finland, Germany, } \\
\text { Ireland, Latvia, UK }\end{array}$ \\
\hline 37 & Cretegny & $\begin{array}{l}\text { International Conference on } \\
\text { Policy Modeling }\end{array}$ & 2002 & $\begin{array}{l}\text { Computable general } \\
\text { equilibrium (CGE) model. }\end{array}$ & Quantitative & Switzerland \\
\hline 38 & $\begin{array}{l}\text { Donnellan \& } \\
\text { Hanrahan }\end{array}$ & $\begin{array}{l}\text { ENARPRI Working Paper } \\
\text { No. } 16\end{array}$ & 2006 & $\begin{array}{l}\text { Partial equilibrium } \\
\text { commodity model and the } \\
\text { satellite GHG and } \\
\text { ammonia emissions } \\
\text { projection models. }\end{array}$ & Quantitative & Ireland \\
\hline 39 & $\begin{array}{l}\text { Lopez-i-Gelats } \\
\text { \& Tabara }\end{array}$ & $\begin{array}{l}\text { Journal of Agricultural and } \\
\text { Environmental Ethics }\end{array}$ & 2010 & Discourse analysis & Qualitative & Europe \\
\hline 40 & Kubičková & $\begin{array}{l}\text { An Enterprise Odyssey: } \\
\text { International Conference } \\
\text { Proceedings }\end{array}$ & 2004 & Case study & Quantitative & $\begin{array}{l}\text { White Carpathians, } \\
\text { Czech Republic }\end{array}$ \\
\hline
\end{tabular}

\section{Actor-oriented Approach}

\begin{tabular}{|c|c|c|c|c|c|c|}
\hline 41 & $\begin{array}{l}\text { Bowen \& De } \\
\text { Master }\end{array}$ & Journal of Rural Studies & 2011 & Comparative case study & Qualitative & France and Poland \\
\hline 42 & Morgan et al. & Journal of Rural Studies & 2010 & Comparative case study & Qualitative & Tuscany and Wales \\
\hline 43 & Arnalte \& Ortiz & $\begin{array}{l}\text { Policies, Governance and } \\
\text { Innovation for Rural Area } \\
\text { International Seminar }\end{array}$ & 2003 & Case study & Qualitative & $\begin{array}{l}\text { Rural regions in } \\
\text { Spain }\end{array}$ \\
\hline 44 & Dufour et al. & Sociologia Ruralis & 2007 & Comparative case study & Qualitative & $\begin{array}{l}\text { Three regions in } \\
\text { Rhône-Alpes } \\
\text { region, France }\end{array}$ \\
\hline 45 & Fleskens et al. & Journal of Rural Studies & 2009 & Case study & Qualitative & $\begin{array}{l}\text { Tras-os-Montes } \\
\text { region, Portugal }\end{array}$ \\
\hline 46 & Gorman et al. & $\begin{array}{l}\text { Journal of Environmental } \\
\text { Policy and Planning }\end{array}$ & 2001 & Case study & Qualitative & Ireland \\
\hline
\end{tabular}



ISSN: 2152-0801 online www.AgDevJournal.com

\begin{tabular}{lllllll}
\hline 47 & Haugan et al. & Farming for Health (book) & 2006 & Historical analysis & Qualitative & Norway \\
\hline 48 & Kasimis et al. & Sociologia Ruralis & 2010 & Case study & Quantitative & $\begin{array}{l}\text { Three farming } \\
\text { regions in Epirus, } \\
\text { Greece }\end{array}$ \\
\hline 49 & $\begin{array}{l}\text { O'Connor \& } \\
\text { Dunne }\end{array}$ & $\begin{array}{l}\text { Journal of Environmental } \\
\text { Policy \& Planning }\end{array}$ & 2009 & Historical analysis & Qualitative & Ireland \\
\hline 50 & $\begin{array}{l}\text { Tipraqsa et al. } \\
\text { Agricultural Systems }\end{array}$ & 2007 & Comparative case study & $\begin{array}{l}\text { Qualitative and } \\
\text { quantitative }\end{array}$ & Northern Thailand \\
\hline
\end{tabular}




\section{Appendix B. Bibliography for All Sample Papers}

Bibliographic Information

Item \# in

Aizaki, H., Sato, K. \& Hiroshi Osari. (2006). Contingent valuation approach in measuring the Appendix A multifunctionality of agriculture and rural areas in Japan. Paddy and Water Environment, 4, 217-222. http://dx.doi.org/10.1007/s10333-006-0052-8

Andersen, P.S., Vejre, H., Dalgaard, T., \& Brandt, J. (2013). An indicator-based method for quantifying farm multifunctionality. Ecological Indicators, 25, 166-179. http://dx.doi.org/10.1016/j.ecolind.2012.09.025

Arnalte, E., \& Ortiz, D. (2003). Some trends of Spanish agriculture. Difficulties to implement a Rural Development model based on the multifunctionality of agriculture. Paper presented at the Policies, Governance and Innovation for Rural Area International Seminar.

Atwell, R. C., Schulte, L. A., \& Westphal, L. M. (2010). How to build multifunctional agricultural landscapes in the U.S. Corn Belt: Add perennials and partnerships. Land Use Policy, 27(4), 1082-1090. http://dx.doi.org/10.1016/j.landusepol.2010.02.004

Aznar, O., Marsat, J., \& Rambonilaza, T. (2007). Tourism and landscapes within multifunctional rural areas: The French case. In U. Mader, H. Wiggering \& K. Helming (Eds.), Multifunctional land use: Meeting future demands for landscape goods and services (pp. 293-303). Berlin, Germany: Springer. http://dx.doi.org/10.1007/978-3-540-36763-5 18

Barbieri, C. \& Valdivia, C. (2010). Recreation and agroforestry: Examining new dimensions of multifunctionality in family farms. Journal of Rural Studies, 26, 465-472. http://dx.doi.org/10.1016/j.jrurstud.2010.07.001

Bjorkhaug, H., \& Richards, C. A. (2008). Multifunctional agriculture in policy and practice? A comparative analysis of Norway and Australia. Journal of Rural Studies, 24, 98-111. http://dx.doi.org/10.1016/j.jrurstud.2007.06.003

Boisvert, R. N., \& Blandford, D. (2006). Multifunctionality and non-trade concerns: Implications for future agricultural policy in Asia. Paddy and Water Environment, 4, 223-228. http://dx.doi.org/10.1007/s10333-006-0053-7

Boody, G., Vondracek, B., Andow, D. A., Krinke, M., Westra, J., Zimmerman, J., \& Wells, P. (2005). Multifunctional agriculture in the United States. BioScience, 55(1), 27-38. http://dx.doi.org/10.1641/0006-3568(2005)055\%5B0027:MAITUS\%5D2.0.C0;2

Bowen, S., \& De Master, K. (2011). New rural livelihoods or museums of production? Quality food initiatives in practice. Journal of Rural Studies, 27, 73-82. http://dx.doi.org/10.1016/j.jrurstud.2010.08.002

Caron, P., Reig, E., Roep, D., Hediger, W., Le Cotty, T., Barthelemy, D., Hadynska, A., Hadynski, J., Oostindie, H. A., \& Sabourin, E. (2008). Multifunctionality: Refocusing a spreading, loose and fashionable concept for looking at sustainability? International Journal of Agricultural Resources, Governance and Ecology,7(4/5), 301-318. http://dx.doi.org/10.1504/IJARGE.2008.020078

Carvalho-Ribeiro, S. M., Lovett, A., \& O'Riordan, T. (2010). Multifunctional forest management in northern Portugal: Moving from scenarios to governance for sustainable development. Land Use Policy, 27, 1111-1122. http://dx.doi.org/10.1016/j.landusepol.2010.02.008

Cretegny, L. (2002). Modelling the multifunctionality of agriculture in a CGE framework. Paper presented at the International Conference on Policy Modeling, Brussels, Belgium.

Crossman, N. D., \& Bryan, B. A. (2009). Identifying cost-effective hotspots for restoring natural capital and enhancing landscape multifunctionality. Ecological Economics, 68, 654-668. http://dx.doi.org/10.1016/j.ecolecon.2008.05.003 
Dibden, J., Potter, C., \& Cocklin, C. (2009). Contesting the neoliberal project for agriculture:

Productivist and multifunctional trajectories in the European Union and Australia. Journal of Rural Studies, 25, 299-308. http://dx.doi.org/10.1016/j.jrurstud.2008.12.003

Donnellan, T., \& Hanrahan, K. (2006). Potential WTO trade reform: Multifunctionality impacts for Ireland (ENARPRI Working Paper No. 16).

Dufour, A., Mauz, I., Rémy, J., Bernard C., Dobremez, L., Havet, A., Pauthenet, Y., Pluvinage, J., \& Tchakérian, E. (2007). Multifunctionality in agriculture and its agents: Regional comparisons. Sociologia Ruralis, 47(4), 316-342. http://dx.doi.org/10.1111/j.1467-9523.2007.00444.x

Fleskens, L., Filomena, D., \& Eicher, I. (2010). A conceptual framework for the assessment of multiple functions of agro-ecosystems: A case study of Tras-os-Montes olive groves. Journal of Rural Studies, 25, 141-155. http://dx.doi.org/10.1016/i.jrurstud.2008.08.003

Gorman, M., Mannion, J., Kinsella, J., \& Bogue, P. (2001). Connecting environmental management and farm household livelihoods: The rural environment protection scheme in Ireland. Journal of Environmental Policy and Planning, 3, 137-147. http://dx.doi.org/10.1002/jepp.76

Grega, L. (2004, June). Valuation of positive externalities of agriculture in south and west Moravia region. In An Enterprise Odyssey: International Conference Proceedings (pp. 214-225). Zagreb, Croatia: University of Zagreb, Faculty of Economics and Business.

Haaland, C., Fry, G., \& Peterson, A., (2011). Designing farmland for multifunctionality. Landscape Research, 36(1), 41-62. http://dx.doi.org/10.1080/01426397.2010.536202

Hadiger, W., \& Lehmann, B. (2003). Multifunctional agriculture and the preservation of environmental benefits. Proceedings of the 35th International Conference of Agricultural Economics (IAAE) Durban, South Africa.

Hartell, J. G. (2004). Pricing benefit externalities of soil carbon sequestration in multifunctional agriculture. Journal of Agricultural and Applied Economics, 36(2), 491-505.

Haugan, L., Nyland, R., Fjeldavli, E., Meistad, T., \& Braastad, B. O. (2006). Green care in Norway: Farms as a resource for the educational, health and social sector. In J. Hassink \& M. Van Dijk (Eds.), Farming for health: Green-care farming across Europe and the United States of America (pp. 109-126). Dordrecht, the Netherlands: Springer.

Hector, A., \& Bagchi, R. (2007). Biodiversity and ecosystem multifunctionality. Nature, 448(7150), 188-190. http://dx.doi.org/10.1038/nature05947

Holmes, J. (2010). Divergent regional trajectories in Australia's tropical savannas: Indicators of a multifunctional rural transition. Geographical Research, 48(4), 342-358. http://dx.doi.org/10.1111/j.1745-5871.2009.00630.x

Hyytia, N., \& Kola, J. (2005). Citizen's attitudes towards multifunctional agriculture. Paper presented at the 99th seminar of the European Association of Agricultural Economics (EAAE), The Future of Rural Europe in the Global Agri-Food System, Copenhagen, Denmark.

Kasimis, C., Papadopoulos, A. G., \& Pappas, C. (2010). Gaining from rural migrants: Migrant employment strategies and socioeconomic implications for rural labour markets. Sociologia Ruralis, 50(3), 258-276. http://dx.doi.org/10.1111/j.1467-9523.2010.00515.x

Kubíčková, S. (2004). Agri-environmental instruments for a landscape amenities protection. In $2^{\text {nd }}$ International Conference: An Enterprise Odyssey: Building Competitive Advantage Proceedings (pp. 295-301).

Lienhoop, N., \& ManMillan, D. (2007). Valuing wilderness in Iceland: Estimation of WTA and WTP using the market stall approach to contingent valuation. Land Use Policy, 24, 289-295. http://dx.doi.org/10.1016/j.landusepol.2005.07.001

Lopez-i-Gelats, F., \& Tabara, J. D. (2010). A cultural journey to the agro-food crisis: Policy discourses in the EU. Journal of Agricultural and Environmental Ethics, 23, 331-344. 
Lovell, S. T., DeSantis, S., Nathan, C. A., Olson, M. B., Méndez, V. E., Kominami, H. C., Erickson, D. L., Morris, K. S., \& Morris, W. B. (2010). Integrating agroecology and landscape multifunctionality in Vermont: An evolving framework to evaluate the design of agroecosystems. Agricultural Systems, 103(5), 327-341. http://dx.doi.org/10.1016/j.agsy.2010.03.003

Lovell, S., Mendez, V., Erickson, D., Nathan, C., \& Desantis, S. (2010). Extent, pattern, and multifunctionality of treed habitats on farms in Vermont, USA. Agroforestry Systems, 80(2), 153-171. http://dx.doi.org/10.1007/s10457-010-9328-5

Milne, R. J., Bennett, L. P., \& Harpley, P. J. (2006). Contributions of landscape ecology, multifunctionality and wildlife research toward sustainable forest management in the Greater Toronto Area. The Forestry Chronicle, 82(3), 403-411. http://dx.doi.org/10.5558/tfc82403-3

Morgan, S. L., Marsden, T., Miele, M., \& Morley, A. (2010). Agricultural multifunctionality and farmers' entrepreneurial skills: A study of Tuscan and Welsh farmers. Journal of Rural Studies, 26, 116-129. http://dx.doi.org/10.1016/j.jrurstud.2009.09.002

O'Connor, D., \& Dunne, W. (2009). Conceptualizing multifunctionality in the Irish policy context: Issues for policy formulation, implementation and evaluation. Journal of Environmental Policy \& Planning, 11(4), 333-346. http://dx.doi.org/10.1080/15239080903033895

Ohe, Y. (2011). Evaluating internalization of multifunctionality by farm diversification: Evidence from educational dairy farms in Japan. Journal of Environmental Management, 92, 886-891. http://dx.doi.org/10.1016/j.jenvman.2010.10.048

Ollikainen, M., \& Lankoski, J. (2005). Multifunctional agriculture: The effect of non-public goods on socially optimal policies (MTT Discussion Papers 1).

Parra-Lopez, C., Groot, J. C. J., Carmona-Torres, C., \& Rossing, W. A. H. (2009). An integrated approach for ex-ante evaluation of public policies for sustainable agriculture at landscape level. Land Use Policy, 26, 1020-1030. http://dx.doi.org/10.1016/j.landusepol.2008.12.006

Râmniceanu, I., \& Ackrill, R. (2007). EU rural development policy in the new member states: Promoting multifunctionality? Journal of Rural Studies, 23(4), 416-429. http://dx.doi.org/10.1016/j.jrurstud.2006.10.003

Rossing, W. A. H., Zander, P., Josien, E., Groot, J. C .J., Meyer, B. C., \& Knierim, A. (2007). Integrative modelling approaches for analysis of impact of multifunctional agriculture: A review for France, Germany and the Netherlands. Agriculture, Ecosystems and Environment, 120(1), 41-57. http://dx.doi.org/10.1016/j.agee.2006.05.031

Saltzman, K., Head, L., \& Stenseke, M. (2011). Do cows belong in nature? The cultural basis of agriculture in Sweden and Australia. Journal of Rural Studies, 27, 54-62. http://dx.doi.org/10.1016/j.jrurstud.2010.09.001

Schindler, S., Sebesvari, Z., Damm, C., Euller, K., Mauerhofer, V., Schneidergruber, A., Biro, M., Essl, F., et al. (2014). Multifunctionality of floodplain landscapes: Relating management options to ecosystem services. Landscape Ecology, 29(2), 229-244. http://dx.doi.org/10.1007/s10980014-9989-y

Soliva, R., Ronningen, K., Bella, I., Bezek, P., Cooper, T., Flo, B. E., Marty, P., \& Potter, C. (2008). Envisioning upland futures: Stakeholders responses to scenarios for Europe's mountain landscapes. Journal of Rural Studies, 24, 56-71. http://dx.doi.org/10.1016/j.jrurstud.2007.04.001

Sumelius, J., \& Bäckman, S. (2008). Review of studies on the establishment and management of policies for multifunctionality. International Journal of Agricultural Resources, Governance and Ecology, 7 (4/5), 386-398. http://dx.doi.org/10.1504/IJARGE.2008.020085

Sutherland, L., Barnes, A., McCrum, G., Blackstock, K., \& Toma, L. (2011). Towards a cross-sectoral analysis of land use decision-making in Scotland. Landscape and Urban Planning, 100, 1-10. http://dx.doi.org/10.1016/i.landurbplan.2010.10.005 
Tipraqsa, P., Craswell, E. T., Noble, A. D., \& Schmidt-Vogt, D. (2007). Resource integration for multiple benefits: Multifunctionality of integrated farming systems in northeast Thailand. Agricultural Systems, 94(3), 694-703. http://dx.doi.org/10.1016/j.agsy.2007.02.009

Turpin, N., Dupraz, P., Thenail, C., Joannon, A., Baudry, J., Herviou, S., \& Verburg, P. (2009). Shaping the landscape: Agricultural policies and local biodiversity schemes. Land Use Policy, 26, 273-283. http://dx.doi.org/10.1016/i.landusepol.2008.03.004

Waldhardt, R., Back, M., Borresch, R., Breuer, L., Diekotter, T., Frede, H., Gath, S., Ginzler, O., et al. (2010). Evaluating today's landscape multifunctionality and providing an alternative future: A normative scenario approach. Ecology and Society, 15(3), 30-50.

Zander, P., Groot, J. C. J., Josien, E., Karpinski, I., Knierim, A., Meyer, B. C., Madureira, L., Rambonilaza, M., \& Rossing, W. A. H. (2008). Farm models and economic valuation in the context of multifunctionality: A review of approaches from France, Germany, The Netherlands and Portugal. International Journal of Agricultural Resources, Governance and Ecology, 7(4/5), 339-360. http://dx.doi.org/10.1504/IJARGE.2008.020084 